\title{
Molecular detection of hepatitis $E$ virus in feces and slurry from swine farms, Rio Grande do Sul, Southern Brazil
}

[Deteç̧ão molecular do vírus da hepatite E em fezes e chorume de propriedades suinícolas, Rio Grande do Sul, Sul do Brasil]

\author{
J. Vasconcelos ${ }^{1}$, M.C. Soliman ${ }^{1}$, R. Staggemeier ${ }^{1}$, L. Heinzelmann ${ }^{1}$, L. Weidlich ${ }^{2}$, \\ R. Cimirro $^{2}$, P.A. Esteves ${ }^{3}$, A.D. Silva ${ }^{3}$, F.R. Spilki ${ }^{1 *}$ \\ ${ }^{1}$ Universidade Feevale - Novo Hamburgo, RS \\ ${ }^{2}$ Centro Universitário Univates -Lajeado, RS \\ ${ }^{3}$ EMBRAPA Suínos e Aves - Concórdia, SC
}

\begin{abstract}
Hepatitis E virus (HEV) is highly disseminated among swine herds worldwide. HEV is also a threat to public health, since particularly genotypes 3 and 4 may cause acute hepatitis in human beings. No previous studies were done on the occurrence of HEV in environmental samples in Rio Grande do Sul, Brazil. In the present study, reverse transcriptase-polymerase chain reaction (RT-PCR) was employed to detect the presence of HEV in swine feces and in effluents from slurry lagoons in farms located in the municipality of Teutônia, inside the area of swine husbandry in the state. Pooled fecal samples from the floor of pig barns from 9 wean-to-finish farms and liquid manure samples were collected from the slurry lagoons from 8 of these farms. From the pooled fecal samples, 8/9 were positive for the HEV ORF1 gene by RT-PCR; all the slurry lagoon samples were positive for HEV RNA (100\%). The identity of the HEV ORF1 amplicons was confirmed by sequencing belonging to HEV genotype 3, which was previously shown to be circulating in South America.
\end{abstract}

Keywords: Hepatitis E virus, swine HEV, slurry, zoonosis

\section{RESUMO}

$\mathrm{O}$ vírus da hepatite $\mathrm{E}$ (HEV) é altamente disseminado entre rebanhos suínos no mundo todo. O HEV é também uma ameaça à saúde pública, já que os genótipos 3 e 4 podem causar hepatite aguda em seres humanos. Não há estudos anteriores sobre a ocorrência de HEV em amostras ambientais no Rio Grande do Sul. No presente estudo, empregou-se transcrição reversa e reação em cadeia da polimerase (RT-PCR) para detectar a presença de HEV em fezes de suínos e efluentes de lagoas de chorume em fazendas localizadas no município de Teutônia, representativo da região de maior produção de suínos no estado. Pools de amostras fecais foram coletadas a partir do chão de galpões de suínos provenientes de 9 propriedades de terminação; outra amostra de esterco líquido foi coletada das lagoas de chorume de 8 dessas fazendas. A partir das amostras fecais reunidas, 8/9 foram positivas para o gene ORF1 de HEV por PCR convencional; todas as amostras de lagoas de chorume foram positivas para RNA de HEV (100\%). A identificação dos produtos de amplificação de HEV ORF1 foi confirmada por sequenciamento pertencente ao HEV genótipo 3, o qual foi previamente detectado na América do Sul.

Palavras-chave: Vírus da Hepatite E, HEV suíno, chorume, zoonoses

\section{INTRODUCTION}

Hepatitis E virus (HEV) is a non-enveloped virus of the Hepeviridae family, being the sole member of the Hepevirus genus. The virus is found in mammal and avian species and is

Recebido em 3 de junho de 2014

Aceito em 3 de março de 2015

*Autor para correspondência (corresponding author)

E-mail: fernandors@feevale.br excreted on feces from infected individuals (Meng, 2011). Four genotypes were described for mammalian HEV strains; genotypes 3 and 4 were described infecting both pigs and humans (Dong et al., 2011). The phylogenetic characterization of all Brazilian HEV samples detected so far demonstrated that they are related 
to genotype 3, first reported in the United States of America, as well as detected later in Argentine, Uruguay and other South American countries (Munné et al., 2006; Mirazo et al., 2011).

The infection in swine is often subclinical, characterized only by mild to moderate microscopic lesions in the liver (Meng, 2011). On the other hand, the infections in human beings may lead to the development of acute hepatitis, and an alarming level of mortality rate in pregnant women (Meng, 2011).

HEV is often considered ubiquitous in swine herds in the USA and other countries. Viruscontaining feces are thought to be the main source of contamination in other pigs, humans and environmental matrices (Fernández-Barredo et al., 2006; Meng, 2011). The virus may also infect humans through the consumption of undercooked meat and by close contact with swine (Meng, 2011).

Previous studies showed the presence of HEV in swine feces, manure and effluents from slaughterhouses (Kasorndorkbua et al., 2005; dos Santos et al., 2011). In a recent study, HEV was detected in $63 \%$ of Brazilian swine herds (Gardinalli et al., 2012). HEV was also detected before in $9.6 \%$ of bile samples as well as in $50 \%$ of the effluents from slaughterhouses in the Rio de Janeiro state, Southeast Brazil (Dos Santos et al., 2011). Serological markers also demonstrated the presence of HEV infections in humans and an autochthonous was described in the last decade in the Southeast and Central Western regions of Brazil (De Souza et al., 2012, Dos Santos et al., 2009; 2000; Lopes dos Santos et al., 2010; Paiva et al., 2007). The occurrence of HEV in environmental samples in Rio Grande do Sul, a major state for Brazilian pork production, was not reported so far. In the present study, the presence of HEV was assessed by nested reverse transcriptase-polymerase chain reaction (nested RT-PCR) in swine feces and effluents from slurry lagoons collected at the municipality of Teutônia, Rio Grande do Sul, the southernmost state of Brazil, which harbors one of the greatest swine populations in the country.

\section{MATERIALS AND METHODS}

Samplings were conducted in nine (9) swine farms located in the rural area of Teutônia $\left(29^{\circ}\right.$
26' 52" S; 51 48' 21" W), Rio Grande do Sul, Brazil. The city of Teutônia is one of the largest swine producers in Rio Grande do Sul and a great public initiative for decontamination of water bodies was initiated at the time of this study and that is the reason why the sampling was done in these farms. The farms are exclusively devoted to swine husbandry and had an average of 406 animals, with ages ranging from 2 to 8 months (wean-to-finish). Pooled fecal samples were collected from the floor of two pens from each pig barn. Another $500 \mathrm{~mL}$ samples from the slurry lagoon receiving the liquid manure of these barns were collected (except for one farm); all samples were collected aseptically in sterile glass bottles. Biological samples were not collected directly from the animals neither were they handled for sampling.

The RTP DNA/RNA Virus Mini Kit (Invitek ${ }^{\mathrm{TM}}$, Germany) was used for extraction of viral nucleic acids, according to the manufacturer's instructions. For wastewater samples, $400 \mu \mathrm{L}$ were used; manure samples were previously diluted $50 \% \mathrm{v} / \mathrm{v}$ onto Eagle's Minimum Essential Medium (E-MEM) and centrifuged at 18,000 x $g$ for $10 \mathrm{~min}$. $400 \mu \mathrm{l}$ of supernatant were then submitted to RNA extraction. Total RNA was stored at $-80^{\circ} \mathrm{C}$ until processing.

Synthesis of cDNA was carried out using the High Capacity cDNA Reverse Transcription ${ }^{\mathrm{TM}}$ kit (Applied Biosciences ${ }^{\mathrm{TM}}$, USA), using random primers and RNAse Inhibitor (Applied Biosciences $^{\mathrm{TM}}$, USA). To a $20 \mu$ reaction volume, $10 \mu \mathrm{l}$ of total RNA obtained in the previous step were added by $2 \mu \mathrm{l}$ of Buffer, $0.8 \mu \mathrm{l}$ of dNTP Mix, $2.0 \mu$ l of Random Primers, $4.2 \mu 1$ of DNase/RNase free water and $1.0 \mu 1$ Reverse Transcriptase enzyme. The reaction was performed in a Labnet $^{\circledR}$ thermal cycler by incubation at $25^{\circ} \mathrm{C}$ for $10 \mathrm{~min}$, followed by $37^{\circ} \mathrm{C}$ for $120 \mathrm{~min}$, and $85^{\circ} \mathrm{C}$ for $5 \mathrm{~min}$.

Detection of the HEV genome was performed by adaptation of previously published RT NestedPCR and RT-PCR assays (Erker et al., 1999). A Swine-HEV genotype 3 positive sample (dos Santos et al., 2011), kindly provided by Dr. Marcelo Alves Pinto (FIOCRUZ, RJ) was used as positive control throughout; MilliQ ${ }^{\circledR}$ water was used as negative control. The reactions were made in a final volume of $50 \mu 1$, containing $25 \mu 1$ of a Promega ready mix 
kit, $18 \mu \mathrm{l}$ of DNase/RNase free water, $1 \mu \mathrm{L}$ of each of the oligonucleotides and $5 \mu \mathrm{l}$ of DNA obtained from cDNA. The oligonucleotides and the cycling conditions were the same proposed by Erker et al. (1999) and Wang et al. (1999). The Nested-RT-PCR oligonucleotides targeted the ORF1 gene 5'-CTGGCATYACTACTGCYATTGA-3' (external sense); 5'-CCATCRARRCAGTAAGTGCGGTC-3' (external anti-sense) and 5'-CTGCCYTKGCGAATGCTGTGG-3' (internal sense); 5'-GGCAGWRTACCARCGCTGAACATC-3' (internal anti-sense).

The reaction consisted of an initial step of $5 \mathrm{~min}$ at $94^{\circ} \mathrm{C}$, followed by 30 cycles of $94^{\circ} \mathrm{C}$ for denaturation (30s), $1 \mathrm{~min}$ at $57^{\circ} \mathrm{C}$ for annealing of primers, and $1 \mathrm{~min} 72^{\circ} \mathrm{C}$ for extension. The mixture was then left for $7 \mathrm{~min}$ at $72^{\circ} \mathrm{C}$ for final extension.

All procedures were performed in safety cabinets to avoid cross-contamination of the samples. After running in a $1 \%$ agarose gel electrophoresis, the PCR products were stained with SYBR Safe ${ }^{\mathrm{TM}}$ dye (Invitrogen ${ }^{\circledR}$ ) and viewed under UV light. The ORF1 expected amplicons were $287 \mathrm{bp}$.

Two of the PCR products of the ORF1 amplicons were randomly chosen and submitted to nucleotide sequencing to confirm its identity. PCR products were purified using GFX PCR and Gel DNA purification kit (GE Healthcare, Giles, United Kingdom). Sequencing was carried out with the DYEnamic ET terminators sequencing kit (GE Healthcare, Giles, United Kingdom) following the manufacturer's protocol. Sequence determination was performed in a MegaBACE 500 automatic sequencer (GE Healthcare). Each product was sequenced at least two times in both directions using forward and reverse primers described above. The nucleotide sequences obtained were compared to other Brazilian and worldwide distributed homologous sequences retrieved from the Genbank (De Souza et al., 2012; Dos Santos et al., 2011; Gardinalli et al., 2012; Mirazo et al., 2011; Paiva et al., 2007).

The quality of DNA sequences was checked and overlapping fragments were assembled using the
BioEdit software 7.0.5 (Hall, 1999). Assembled sequences with high quality were aligned using Clustal X (Thompson et al., 1997) with default gap penalties. The phylogenetic relationship between these protein sequences was performed with MEGA 6.06 (Tamura et al., 2013). Neighbor-joining trees were constructed from Kimura-2 parameters and calculated using pairwise deletion. That protocol was chosen after the test of the model that best fits for the nucleotide substitutions patterns found in the nucleotide alignments using MODELTEST (http://www.molecularevolution.org/software/ph ylogenetics/modeltest). Bootstrap was resampled as a test of phylogeny using 500 replications and a total of 228 positions were used in the final dataset. An avian hepatitis E homologous gene sequence was used as an out-group.

\section{RESULTS}

Results are summarized on Table 1. Eight of the nine pooled fecal samples collected from the floor of pig barns were positive for HEV RNA. From the effluent samples, $7 / 8$ of the farms were positive for HEV; Fig. 1 shows an example of the results obtained for RT-nested-PCR analysis.

Table 1. Detection of HEV RNA in pooled fecal samples and on the slurry from pig farms located in Rio Grande do Sul, Brazil

\begin{tabular}{lcc}
\hline Farm \# & Pooled feces & Slurry lagoon \\
\hline 1 & + & + \\
2 & + & + \\
3 & + & + \\
4 & + & + \\
6 & + & + \\
7 & + & + \\
8 & - & + \\
9 & + & NC \\
\hline \multicolumn{4}{l}{ Positive; - = negative }
\end{tabular}

All the sequenced amplicons were included in the genotype 3 of $\mathrm{HEV}$ when compared to the homologous nucleotide sequences available in Genbank. The phylogenetic analysis of the ORF1 amplicon sequences from two of the samples showed that they may be classified within the genotype 3, and clustered together with recent Brazilian isolates of swine HEV within the subgenotype $3 b$ (Figure 2). 


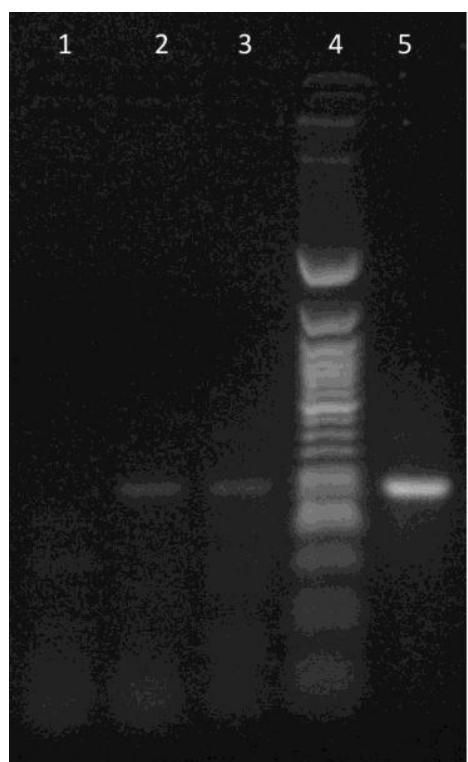

Figure 1. RT-nested-PCR for the detection of a fragment of the ORF2 gene of hepatitis E virus, showing negative control (lane 1), a pooled fecal sample (7A, lane 2), slurry sample (7B, lane 3) M is 100 bp molecular weight marker (lane 4) and positive control (lane 5). Amplicons of approximately $287 \mathrm{bp}$ are seen under ultraviolet light in a $2 \%$ agarose gel stained with SYBR $^{\circledR}$ Safe (Invitrogen, Carlsbad, California).

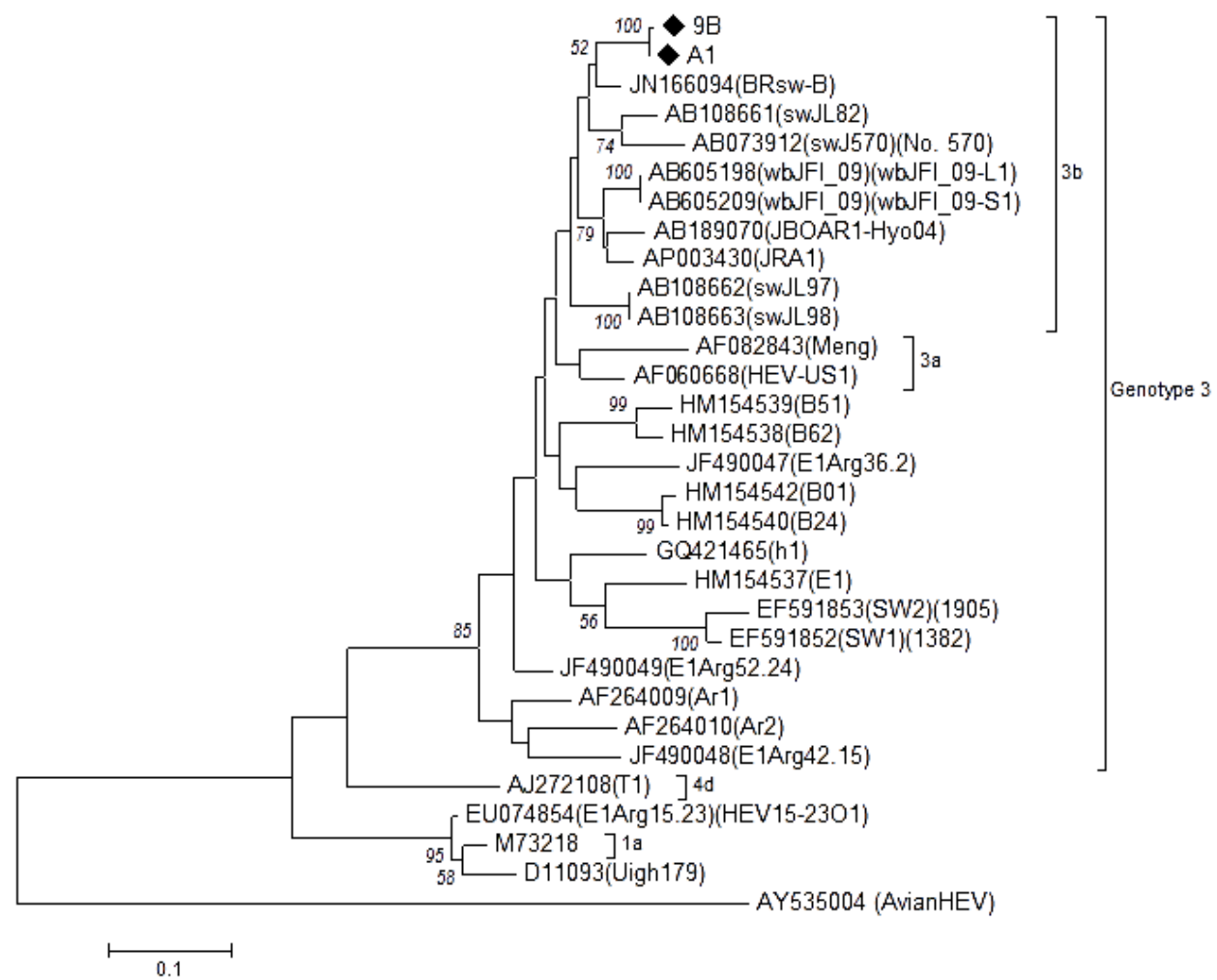

Figure 2. Phylogenetic tree constructed by the neighbor-joining method based on the partial sequences of HEV ORF1 gene. The nucleotide sequences found in the present study (9B and A1) are narrowed with diamonds. An AvianHEV homologous sequence was used as an out-group. Bootstrap values below 50 are not shown. 


\section{DISCUSSION}

HEV is present worldwide in swine herds. Previous studies conducted in Brazilian herds have shown the exposure of swine handlers to the virus by the presence of specific antibodies; HEV-RNA was also found on effluents from farms and slaughterhouses in South-East and Central-East Brazil, and the Amazon region, indicating that HEV is widespread among Brazilian swine herds (de Souza et al., 2012; dos Santos et al., 2011; dos Santos et al., 2009). However, the region of the study is a major producer of pork products, both for internal consumption and exportation and no previous studies were conducted before, especially in environmental samples.

From the results obtained here it is possible to conclude that HEV circulates in all farms analyzed. HEV RNA was found in slurry lagoon samples from all farms and in fecal samples from 8 out of 9 farms included in this study. This occurrence is elevated when compared to those reported before in other Brazilian regions and for other countries (Kasorndorkbua et al., 2005); this area has a great density of farms and the production is mainly based on highly intensive systems, which may influence the levels of occurrence of HEV as reported before (Da Costa Lana et al., 2014). This may be due to an elevated prevalence of $\mathrm{HEV}$ in this region, a better efficacy of the protocols used for RNA extraction, concentration of the samples or climatic factors (such as temperature and rainfall) may have favored the detection of $\mathrm{HEV}$ RNA in all samples in the present study.

The HEV subgenotype $3 b$ was found in the samples and it is consistent with the previous phylogenetic studies conducted from swine, slaughterhouse effluents and human hepatitis samples in Brazil, thus indicating that this genetic type is prevalent in the country, regardless of the region of study (Lopes dos Santos et al., 2010; Paiva et al., 2007; dos Santos et al., 2011). PCR amplification and sequencing of the HEV ORF2 was achieved for the positive samples and the phylogenetic analysis confirmed that these are HEV subgenotype $3 b$ samples (data not shown). Genotype 3 and its subgenotypes are highly prevalent among swine herds, especially in the USA and in Latin American countries, and the virus was recently found also in river water in Cambodia (Kitajima et al., 2009, Mirazo et al., 2011).

These results may be a matter of concern for public health, since the surface and groundwater bodies of this region are likely to be contaminated by HEV genotype 3. This particular HEV genotype is considered zoonotic and the causative agent of the laboratory confirmed cases of hepatitis $\mathrm{E}$ in human beings in Brazil and Uruguay (Lopes dos Santos et al., 2010; Mirazo et al., 2011). Swine manure and the slurry lagoon effluents are often used as soil fertilizers and these practices may contaminate both drinking water and water used for irrigation of vegetables. It may be a concern for the specific region of the study since a higher endemicity of $\mathrm{HEV}$ in human populations is expected where sanitary conditions are poor (Swain et al., 2010); another problem is that there are no national guidelines for routine laboratory diagnosis of Non-A/Non-B/Non-C hepatitis in Brazil.

\section{CONCLUSIONS}

The detection of HEV RNA in environmental samples points to the need for better management practices for slurry treatment to avoid the dissemination of HEV to water bodies and minimize the related zoonotic risk to neighboring populations. HEV may also be found in pork meat and its byproducts, thus further efforts for an investigation of the prevalence of $\mathrm{HEV}$ in both swine and environmental matrices should be conducted on these same regions in the near future. Due to HEV zoonotic risk, fast and reliable tools for monitoring of slaughtered animals should be adopted (Aggarwal and Jameel, 2011; Dong et al., 2011; Meng, 2011). Moreover, efficient preventive measures to avoid the infection of pigs and the treatment of wastewater from animal facilities are also needed.

\section{ACKNOWLEDGEMENTS}

This study was funded by the Conselho Nacional de Desenvolvimento Científico e Tecnológico (CNPq) and Fundação de Amparo à Pesquisa do Estado Rio Grande do Sul (FAPERGS). FRS is a $\mathrm{CNPq}$ research fellow. 


\section{REFERENCES}

COSTA LANA, M.V.; GARDINALI, N.R.; DA CRUZ, R.A. et al. Evaluation of hepatitis E virus infection between different production systems of pigs in Brazil. Trop. Anim. Health Prod., v.46, p.399-404, 2014.

DONG, C.; MENG, J.; DAI, X. et al. Restricted enzooticity of hepatitis E virus genotypes 1 to 4 in the United States. J. Clin. Microbiol., v.49, p.4164-4172, 2011.

ERKER, J.C.; DESAI, S.M.; MUSHAHWAR, I.K. Rapid detection of Hepatitis E virus RNA by reverse transcription-polymerase chain reaction using universal oligonucleotide primers. J. Virol. Methods, v.81, p.109-113, 1999.

FERNÁNDEZ-BARREDO, S.; GALIANA， C.; GARCÍA, A. et al. Detection of hepatitis E virus shedding in feces of pigs at different stages of production using reverse transcription-polymerase chain reaction. J. Vet. Diagn. Invest., v.18, p.462-465, 2006.

GARDINALI, N.R.; BARRY, A.F.; SILVA, P.F. et al. Molecular detection and characterization of hepatitis $\mathrm{E}$ virus in naturally infected pigs from Brazilian herds. Res. Vet. Sci., v.93, p. 1515-1519, 2012.

HALL, T.A. BioEdit: a user-friendly biological sequence alignment editor and analysis program for Windows 95/98/NT. Nucl. Acids. Symp. Ser., v.41, p.95-98, 1999.

KASORNDORKBUA， C.; OPRIESSNIG, T.; HUANG, F. F.et al. Infectious swine hepatitis E virus is present in pig manure storage facilities on United States farms, but evidence of water contamination is lacking. Appl. Environ. Microbiol., v.71, p.7831-7837, 2005

KITAJIMA, M.; MATSUBARA, K.; SOUR, S. et al. First detection of genotype 3 hepatitis E virus RNA in river water in Cambodia. Trans. Royal Soc. Trop. Med. Hyg., v.103, p.955-957, 2009.

LOPES DOS SANTOS, D.R.; LEWIS-XIMENEZ, L.L.; DA SILVA, M.F.M. et al. First report of a human autochthonous hepatitis $\mathrm{E}$ virus infection in Brazil. J. Clin. Virol., v.47, p.276-279, 2010.

MENG, X.J. From barnyard to food table: The omnipresence of hepatitis E virus and risk for zoonotic infection and food safety. Virus Res., v.161, p.23-30, 2011.
MIRAZO, S.; RAMOS, N.; RUSSI, J.C. Detection and molecular characterization of sporadic cases of acute human hepatitis E virus infection in Uruguay. Arch. Virol., v.156, p.1451-1454, 2011.

MUNNÉ, M.S.; VLADIMIRSKY, S.; OTEGUI, L. et al. Identification of the first strain of swine hepatitis $\mathrm{E}$ virus in South America and prevalence of anti-HEV antibodies in swine in Argentina. J. Med. Virol., v.78, p.1579-1583, 2006.

PAIVA, H.H.; TZANEVA, V.; HADDAD, R.; YOKOSAWA, J. Molecular characterization of swine hepatitis E virus from southeastern Brazil. Braz. J. Microbiol., v.38, p.693-698, 2007.

SANTOS, D.R.L.; PAULA, V.S.; OLIVEIRA, J.M. et al. Hepatitis E virus in swine and effluent samples from slaughterhouses in Brazil. Vet. Microbiol., v.149, p.236-241, 2011.

SANTOS, D.R.L.; VITRAL, C.L.; PAULA, V.S. et al. Serological and molecular evidence of hepatitis $\mathrm{E}$ virus in swine in Brazil. Vet. J., v.182, p.474-480, 2009.

SOUZA, A.J.S.; GOMES-GOUVÊA, M.S.; SOARES, M.D.C.P. et al. HEV infection in swine from Eastern Brazilian Amazon: evidence of co-infection by different subtypes. Comp. Immunol. Microbiol. Inf. Dis., v.35, p.477-485, 2012.

SWAIN, S.K.; BARAL, P.; HUTIN, Y.J. et al. A hepatitis E outbreak caused by a temporary interruption in a municipal water treatment system, Baripada, Orissa, India, 2004. Trans. Royal Soc. Trop. Med. Hyg., v.104, p.66-69, 2010.

TAMURA, K.; STECHER G.; PETERSON, D. et al. MEGA 6: molecular evolutionary genetics analysis. Version 6.0. Mol. Biol. Evol. v.30, p.2725-2729, 2013

THOMPSON, J.D.; GIBSON, T.J.; PLEWNIAK, F. et al. The CLUSTAL_X windows interface: flexible strategies for multiple sequence alignment aided by quality analysis tools. Nuc. Acids Res., v.25, p.48764882, 1997.

WANG, Y.; LING, R.; ERKER, J.C. et al. A divergent genotype of hepatitis $\mathrm{E}$ virus in Chinese patients with acute hepatitis. J. Gen. Virol., v.80, p.169-177, 1999. 